\title{
Laparoscopic Intragastric Surgery for Treating Early Gastric Cancer
}

\author{
EDOARDO VIRGILIO ${ }^{1}$, GENOVEFFA BALDUCCI ${ }^{1}$, PAOLO MERCANTINI ${ }^{1}$, \\ ENRICO GIARNIERI ${ }^{2}$, MARIA ROSARIA GIOVAGNOLI ${ }^{2}$, MONICA MONTAGNINI $^{2}$, \\ ANTONELLA PROIETTI ${ }^{2}$, ROSARIA D'URSO ${ }^{2}$ and MARCO CAVALLINI ${ }^{1}$ \\ Departments of ${ }^{1}$ Medical and Surgical Sciences and Translational Medicine, and ${ }^{2}$ Clinical and Molecular Medicine, \\ Faculty of Medicine and Psychology, Sapienza University, St. Andrea Hospital, Rome, Italy
}

\begin{abstract}
Background/Aim: Although there is an increasing number of studies on laparoscopic resection of early gastric cancer (EGC), as of 2018 no standardized strategy exists. We reviewed available literature dealing with laparoscopic intragastric (intraluminal) surgery (LIGS) conducted for patients with EGC to better define indications, benefits and limitations of this particular minimally invasive technique. Materials and Methods: PubMed, MEDLINE, Science Direct, Scopus, Web of Science, Google Scholar and ResearchGate were the search engines investigated. Only LIGS for EGC was entertained; studies conducted for other gastric diseases were excluded. Suitable articles written in all languages were included in the review. Results: As of 2018, we found 19 studies dealing with LIGS for EGC: studies on 72 humans and four pigs were identified. Among 72 human participants, there were 59 mucosal, five submucosal and one subserosal cancer. Conclusion: Based on our review, LIGS appears as a cogent option to endoscopic resection for treating superficial EGC.
\end{abstract}

In the past two decades, better knowledge on pathobiology of gastrointestinal stromal tumor (GIST) and early gastric cancer (EGC), as well as the more frequent detection of these two diseases, have increased the interest in minimally-invasive resection techniques (1). On the one hand, endoscopists have

Correspondence to: Dr. Edoardo Virgilio, Department of Medical and Surgical Sciences and Translational Medicine, Division of General Surgery, Faculty of Medicine and Psychology, Sapienza University, St. Andrea Hospital, via di Grottarossa 1035-39, Rome 00189, Italy. Tel: +39 0633775989, Fax: +390633775322 e-mail: aresedo1992@yahoo.it, edoardo.virgilio@uniroma1.it

Key Words: Early gastric cancer, laparoscopy, intragastric surgery, intraluminal surgery, intragastric mucosal resection, intragastral resection, review. developed techniques such as endoscopic mucosal resection (EMR), endoscopic submucosal dissection (ESD) and endoscopic full-thickness resection (EFTR); on the other hand, due to the evolution of laparoscopy, gastrointestinal surgeons approach GC by switching progressively from traditional interventions to minimally invasive segmental resections (1). Among the new possibilities, the combination of laparoscopy with endoscopy, the so-called hybrid laparoscopic approach, represents one of the most interesting procedures. With reference to dissection and resection of the tumor, the hybrid approach includes two main types of procedures: in the former, laparoscopy resects the tumor under endoscopic guidance, in the latter endoscopy and laparoscopy cooperate on an equal basis (1). Endoscope-assisted laparoscopic wedge resection and laparoscopic intragastric (intraluminal) surgery (LIGS) belong to the first group, whereas laparoscopic endoscopic cooperative surgery (LECS), laparoscopy-assisted EFR, clean non-exposure technique and non-exposed endoscopic wall-inversion surgery form the second (1-20). Irrespective of the adopted choice, common objectives of all techniques are an easier approach to the gastric lesion, shorter length of hospital stay with minor economic impact and respect for oncological principles. Regarding LIGS, as of 2018, pertinent studies enrolled patients with both benign and malignant lesions, making the actual evaluation of this practice in GC difficult (2-20). Furthermore, most work combined LIGS with other minimally invasive treatments, rendering the appraisal even more laborious (2-20). Herein, we offer a systematic review of the literature dealing with LIGS performed for EGC only: to date, as far as we are aware, no report of such a dedicated effort has been published.

\section{Materials and Methods}

We systematically reviewed world literature dealing with LIGS for EGC; studies or data on LIGS conducted for other gastric diseases were excluded. With this intent, seven popular search engines were investigated (PubMed, MEDLINE, Science Direct, Scopus, Web of 
Science, Google Scholar and Research Gate). "Intragastric surgery", "laparoscopic intragastric surgery", "minimally invasive intragastic surgery", "robotic intragastric surgery", "EGC and "GC" were the key words utilized for searching. Suitable articles written in any language from 1994 until 2018 were included in the review.

\section{Results}

We found 19 studies dealing with LIGS for patients with EGC (2-20). Table I summarizes the principle features of the studies included in this review.

Surgical technique: original description and following variants. The first to pioneer LIGS was Ohashi in 1994 (2). He introduced this new technique for three patients affected with different gastric lesions: giant polyp, submucosal tumor (leiomyoma), and mucosal EGC (2) (Figure 1). All the lesions measured $2 \mathrm{~cm}$ in diameter and were located at the cardia, fornix and on the posterior wall of gastric body. LIGS resulted from a combination of laparoscopy with endoscopy and can be briefly described as follows (Figure 1): general anesthesia, peroral insertion of a gastroscope to visualize the gastric lesion, placement and inflation of a balloon (inserted along with a nasogastric tube) in the duodenum to prevent air flowing from the stomach to the intestine, insertion and fixation of three trocars in the stomach (three different methods are possible) under gastroscope guidance, laparoscopic mucosal resection, specimen extraction by gastroscope via the mouth or by a bag through the trocar, bleeding control and closure of the abdomen. Ohashi outlined two main features of this technique: lesions located in any part of the stomach were amenable to LIGS except those of the anterior gastric wall because of the technical difficulty; the resected gastric portion could be left untreated as a mucosal defect since gastroscopic examination performed on all patients 1 to 2 weeks after the operation demonstrated complete healing in all cases $(2,3)$. In 1996, however, Lai and colleagues preferred to suture mucosal defects through a minilaparotomy (4). Since then, the two approaches to mucosal defects (conservative vs. operative) varied through articles, sometimes leaving the mucosal defect untreated according to Ohashi's method (12), other times comparing both options $(8,10)$. However, there are also cases in which no mention was provided (13). In 2009, Yumiba et al. prospectively demonstrated that mucosal defect healing was faster and more advantageous in economic terms following closure with a continuous suturing of 4-0 Vicryl than an observational method $(p \leq 0.014)(10)$. In addition to absorbable suture material, fibrin coating also represented an occasional method for sealing (9).

Concerning the depth of dissection following mucosal excision, differently from submucosal tumors, where it is deepened to the muscular layer, in the case of EGC, it is confined to submucosal plane (7). In 2009, however, Wong and coauthors performed a deeper dissection: combining LIGS with endoscopy (endolaparoscopic intragastric tumor excision) to treat 12 patients with gastric lesions (including two tumors with provisional diagnosis of EGC), they associated an endoscopic submucosal resection with laparoscopic seromuscolar dissection (16). As for the trocar types, occasionally intragastric access was unconventionally gained through percutaneous endoscopic gastrostomy (10) or a $5-\mathrm{mm}$ radially expandable sleeve (8). In 2007, Hirano and coauthors first employed robotic intragastric surgery (da Vinci Surgical System) in a porcine model with a tentative EGC sited along the posterior wall of the cardia (20); although the experiment was successful in terms of operative time (approximately 41 minutes only) and absence of complications, to date no robotic attempt on humans has been reported.

Main features of enrolled patient populations. Altogether, 72 patients with EGC patients were reported to have undergone LIGS (2-18). Age and sex were not always reported; among the detailed data, the age ranged between 59 and 82 years (3, 13). Regarding the mucosal depth of EGC invasion, there were 59 cases of T1a and five of T1b cancer; information was lacking for seven patients. Additionally, one lesion with provisional diagnosis of EGC had invaded into the subserosa (pT2b or pT3 according to the sixth or seventh edition of the American Joint Commitee on Cancer (AJCC) tumor node metastasis staging system for GC, respectively] (16). Tumor size, where declared, ranged from 0.5 to $3 \mathrm{~cm}(5,16)$. The posterior wall of the gastric body was the most frequent site of EGC in 32 definite cases; the anterior wall of the gastric stump and cardia were described in one and three cases, respectively $(3,13,17,18)$. Besides the 72 human participants, LIGS was also adopted for four porcine models $(19,20)$.

Clinical and oncological outcome. Surgery-related complications included three cases of stenosis at the gastric cardia (treated with repeat endoscopic dilatations) $(5,6)$, one perforation (necessitating repair though laparotomy) (9), tub cases of bleeding flowing from mucosal defect (treated conservatively in the former and with open conversion in the latter) $(12,14)$ and one hemorrhage from an abdominal port site managed with re-laparoscopy (16).

Surgical margins of the specimen showed infiltration (R1) in three cases. One R1 case derived from a T1b cancer of the antrum: the authors entertained distal gastrectomy as corrective surgery, but a decision had not yet been undertaken at the time of publication (11). Another R1 lesion originated from a T1a EGC: in this patient, reoperation was not immediately performed in expectation of cauterization effects. However, from endoscopic examination at the 28month follow-up, it recurred as EGC stump and distal gastrectomy was performed (14). A further R1 cancer ensued from a cardial ulcer of $3 \mathrm{~cm}$ in diameter which showed 


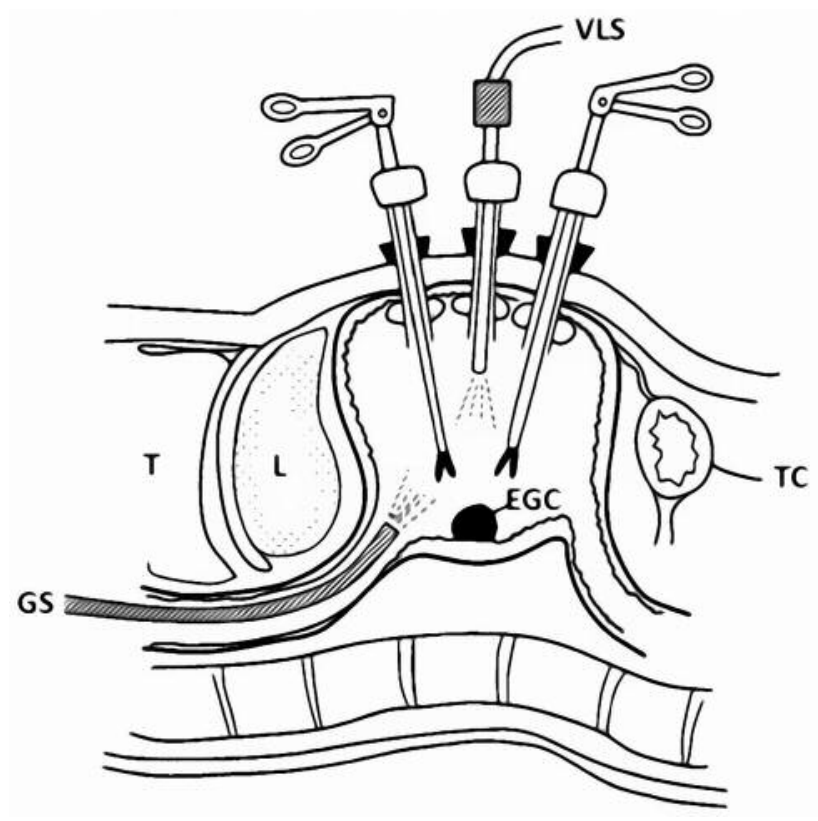

Figure 1. Illustration of laparoscopic intragastric surgery as originally conceived by Ohashi in 1994. VLS: Videolaparoscopy; EGC: early gastric cancer; TC: transverse colon; GS: gastroscope; T: thorax; L: liver.

dysplasia on preoperative endoscopic biopsy; however, final pathology revealed a well-differentiated adenocarcinoma invading into the subserosa (pT2b or pT3 according to the sixth or seventh edition AJCC classification) (16). Hence, in this case, the authors were misled by preoperative findings and conducted LIGS erroneously; as oncological salvage, they adopted laparoscopic-assisted total gastrectomy with an uneventful recovery.

One recurrence was found near the cardia of a patient 2 years after LIGS was carried out for mucosal cardial EGC; as the lesion was only $5 \mathrm{~mm}$ in diameter, the patient was successfully treated by endoscopic laser irradiation (5). Another mucosal recurrence developed 2 years after the initial surgery and was managed with gastrectomy; in this case, however, we were unable to find details as to whether the initial intervention was LIGS or laparoscopic wedge resection $(5,6)$.

Of interest, in 2005, Ludwig and colleagues combined LIGS with sentinel lymph node biopsy in three patients with T1a cancer: no tumor cells were found in dissected lymph nodes (15).

\section{Discussion}

Laparoscopic intragastric (intraluminal) surgery, also termed laparoscopic endoluminal surgery, laparoscopic intragastric mucosal resection or laparoscopic intragastral resection in the reported studies was conceived by Ohashi to provide a minimally invasive successful option for treating those gastric lesions (including EGCs) that were problematic for EMR (2-20). It has been reported that many EMR specimens were histologically positive for cancer at the surgical margin in up to $26 \%$ of cases (14). Thereafter, due to advances in EMR (such as the introduction of insulated-tip electrosurgical knife) and development of ESD and EFTR allowing en-bloc resections of much larger EGCs and reduction of the recurrence rate, employment of LIGS came to a standstill (12). Nevertheless, to date, it still represents a cogent surgical treatment for superficial EGC located at the posterior wall of the stomach as well as in cardial or pyloric regions where EMR and ESD are more difficult to perform (9). Furthermore, the concomitant accomplishment of lymph node dissection and sentinel lymph node biopsy constitutes an advantageous oncological feature (15). However, such a promising technique is not exempt from limitations, complications or potential inconveniences. First of all, it demands surgical skills and a necessary learning curve (12). Second by, lesions located at the anterior gastric wall are excluded from indication for obvious anatomical reasons (laparoscopic trocars are passed through the ventral gastric wall) (2-20). Thirdly, surgery-related complications (such as bleeding, perforation and stenosis), as well as oncological incompleteness (R1 and recurrent cases), can inadvertently take place $(5,6,9$, $11,12,14,16)$. OFinally, although very low and more probable with other hybrid laparoscopic techniques (such as LECS, inverted LECS, laparoscopy-assisted EFR and non-exposed endoscopic wall-inversion surgery, the risk of scattering of cancer cells from gastric lumen to peritoneal cavity remains a possibility $(19,21-25)$. Such a dreaded adverse event can potentially happen when the integrity of the gastric wall is compromised: this is mainly due to the fact that EGC can intragastrically exfoliate following the sixth metastatic route as previously demonstrated (26-31). Any phase of intervention can be affected: the beginning, when the gastric wall is punctured with ports or wires; the in-between course, especially in the case of perforation but also because laparoscopic devices touching and capturing the floating intragastric malignant cells might cause consequent intraperitoneal dissemination; and in the end phase, laparoscopic collection of the specimen might cause tumor implantation in gastric wall defects or abdominal port sites in the case of bag rupture or contaminated laparoscopic devices (32-34). To prevent or reduce the risk of such mishaps, careful endoscopic guidance during laparoscopic intragastric maneuvers, minimal handling of the tumor, as well as preoperative intragastric lavage and postoperative intraperitoneal washing, represent oncologically appropriate prophylactic measures (21-25).

\section{Conclusion}

Among minimally invasive hybrid techniques, LIGS represents a valid option for treating superficial EGC. Randomized controlled trials are welcome to better define the 
Table I. Main features of the available studies dealing with laparoscopic intragastric surgery for early gastric cancer (EGC).

\begin{tabular}{|c|c|c|c|c|c|c|c|c|c|}
\hline $\begin{array}{l}\text { Year/ } \\
\text { reference }\end{array}$ & $\begin{array}{l}\text { Number/ } \\
\text { gender of } \\
\text { patients* }\end{array}$ & $\begin{array}{l}\text { EGC type/ } \\
\text { Size }(\mathrm{cm}) / \\
\text { Site }\end{array}$ & $\begin{array}{c}\text { Means } \\
\text { of } \\
\text { extraction }\end{array}$ & $\begin{array}{l}\text { Operative } \\
\text { time } \\
(\mathrm{min})\end{array}$ & $\begin{array}{c}\text { Blood } \\
\text { loss } \\
(\mathrm{ml})\end{array}$ & $\begin{array}{l}\text { LOS } \\
\text { (mean } \\
\text { days) }\end{array}$ & $\begin{array}{c}\text { Approach to } \\
\text { mucosal } \\
\text { defect }\end{array}$ & $\begin{array}{c}\text { Operative } \\
\text { complications }\end{array}$ & $\begin{array}{c}\text { Follow-up } \\
\text { (months) }\end{array}$ \\
\hline $\begin{array}{l}1994(2), \\
1995(3)\end{array}$ & $\begin{array}{l}10 \text { Patients: } \\
5 \mathrm{M}, 1 \mathrm{~F} \\
4 \mathrm{NA}\end{array}$ & $\begin{array}{c}4 \text { T1a, } 2 \text { T1b, } 4 \text { NA; } \\
\text { Size: } 2,2.5,1.5,2 \\
\text { 2, 2, } 4 \text { NA } \\
\text { Site: C, P, B, } \\
\text { B, B, A, } 4 \text { NA }\end{array}$ & $\begin{array}{l}\text { GS: } 9 \text {; } \\
\text { VLS: } 1\end{array}$ & $\begin{array}{c}\text { 60-150 Mean: } \\
105\end{array}$ & NA & 5 & UMD & None & $\begin{array}{c}\text { Mean: } 9 \\
\text { Maximum: } 15\end{array}$ \\
\hline $1996(4)$ & $\begin{array}{l}\text { 1 Patient } \\
\text { F }\end{array}$ & $\begin{array}{c}\text { EGC type: NA; } \\
\text { Size: NA } \\
\text { Site: } \mathrm{P}(\mathrm{B})\end{array}$ & VLS & 160 & None & 4 & SMD & $\begin{array}{l}\text { Minilaparotomy } \\
\text { to perform } \\
\text { SMD }\end{array}$ & NA \\
\hline $\begin{array}{l}1999(5) \\
2000(6)\end{array}$ & $\begin{array}{l}18 \text { Patients } \\
15 \mathrm{M}, 2 \mathrm{~F} \\
1 \mathrm{NA}\end{array}$ & $\begin{array}{c}16 \text { T1a, } 1 \\
\text { T1b; } 1 \text { NA; } \\
\text { Size: } 0.9(0.5-2.5) \\
\text { Site: NA }\end{array}$ & GS & $\begin{array}{c}\text { 185-405 Mean: } \\
245\end{array}$ & $<50$ & $8(7-14)$ & UMD & $\begin{array}{l}3 \text { Complications } \\
\text { (C stenosis } \\
\text { submitted to } 1 \\
\text { endo-dilatation) }\end{array}$ & $\begin{array}{c}\text { Mean: } \\
34 \text { (3-96); } \\
1 \mathrm{C} \text { recurrence } \\
\text { treated by } \\
\text { endo-laser } \\
\text { irradiation; } \\
\text { another NWA } \\
\text { recurrence }\end{array}$ \\
\hline $2000(7)$ & $\begin{array}{l}1 \text { Patient } \\
\text { NA }\end{array}$ & $\begin{array}{c}1 \mathrm{~T} 1 \mathrm{a} ; \\
\text { Size and Site: NA }\end{array}$ & GS & N.A. & NA & 6 & UMD & None & N.A. \\
\hline $2000(8)$ & $\begin{array}{c}11 \text { Patients; } \\
\text { M: F ratio 8: } 6\end{array}$ & $\begin{array}{c}11 \mathrm{~T} 1 \mathrm{a} ; \\
\text { Size: NA; } \\
\text { Site: NA }\end{array}$ & GS & N.A. & 0 & N.A. & $\begin{array}{l}\text { UMD and } \\
\text { SMD }\end{array}$ & None & $\begin{array}{l}\text { NA (no } \\
\text { recurrence) }\end{array}$ \\
\hline $2002(9)$ & $\begin{array}{l}2 \text { Patients } \\
\text { NA }\end{array}$ & $\begin{array}{c}2 \mathrm{~T} 1 \mathrm{a} ; \\
\text { Size: } 1.6(1.1-2.3) \\
\text { Site: } \mathrm{P}\end{array}$ & GS & $\begin{array}{c}\text { 49-102 } \\
\text { Mean: } 67\end{array}$ & None & $\begin{array}{c}10.2 \\
(6-16)\end{array}$ & SMD & $\begin{array}{l}1 \text { P perforation } \\
\text { repaired with } \\
\text { conversion }\end{array}$ & $\begin{array}{c}\text { Mean: } \\
14.5(9-19)\end{array}$ \\
\hline $2003(10)$ & $\begin{array}{c}4 \text { Patients } \\
\text { M: F ratio 2: } 2\end{array}$ & $\begin{array}{c}4 \mathrm{~T} 1 \mathrm{a} ; \\
\text { Size: } 1.02(0.6-1.3) \text {; } \\
\text { Site: } \mathrm{P}\end{array}$ & NWA & NA & NA & NA & $\begin{array}{l}\text { UMD and } \\
\text { SMD (faster } \\
\text { healing in } \\
\text { SMD group } \\
\mathrm{p} \leq 0.014 \text { ) }\end{array}$ & None & NA \\
\hline 2003 (11) & 2 Patients/NA & $\begin{array}{l}1 \text { T1a, } 1 \text { T1b; } \\
\text { Size: } 1,1.5 ; \\
\text { Site: P }(A, B)\end{array}$ & $\begin{array}{l}\text { GS: } 1 \text {; } \\
\text { PEG: } 1\end{array}$ & NA & NA & NA & NA & $\begin{array}{l}\text { Infiltrated } \\
\text { margins }(\mathrm{R} 1) \\
\text { for } \mathrm{T} 1 \mathrm{~b}\end{array}$ & $\begin{array}{l}\text { Time: NA; } \\
\text { R1: decision } \\
\text { for DG under } \\
\text { examination }\end{array}$ \\
\hline 2003 (12) & $\begin{array}{l}4 \text { Patients; } \\
1 \mathrm{M}, 3 \mathrm{~F}\end{array}$ & $\begin{array}{c}4 \text { T1a; } \\
\text { Size: } 2.3 \pm 1.4 ; \\
\text { Site: P }(3 \mathrm{C}, 1 \mathrm{~B})\end{array}$ & NA & $298 \pm 106$ & $33 \pm 58$ & $16 \pm 3$ & UMD & $\begin{array}{c}\text { Bleeding ( } 1 \text { case) } \\
\text { treated with } \\
\text { conversion }\end{array}$ & NA \\
\hline 2003 (13) & $\begin{array}{c}1 \text { Patient } \\
\mathrm{M}\end{array}$ & $\begin{array}{c}1 \mathrm{~T} 1 \mathrm{a} ; \\
\text { Size: NA; } \\
\text { Site: EGCS }\end{array}$ & NA & N.A. & NA & NA & NA & None & NA \\
\hline 2003 (14) & $\begin{array}{l}7 \text { Patients } \\
4 \mathrm{M}, 3 \mathrm{~F}\end{array}$ & $\begin{array}{c}7 \mathrm{~T} 1 \mathrm{a} ; \\
\text { Size: } 1.04 \\
\text { Site: } \mathrm{P}(2 \mathrm{C}, 3 \mathrm{~B}, 2 \mathrm{~A})\end{array}$ & NA & 210 & 104 & 12.4 & UMD; & $\begin{array}{c}\text { Bleeding (1 case) } \\
\text { treated } \\
\text { conservatively; } \\
1 \mathrm{R} 1 \text { case }\end{array}$ & $\begin{array}{l}\text { Mean: } \\
7.9 \text { years; } \\
\text { R1 case } \\
\text { recurred at } \\
28 \text { months } \\
\text { needing DG }\end{array}$ \\
\hline 2005 (15) & $\begin{array}{c}6 \text { Patients } \\
\text { NA }\end{array}$ & $\begin{aligned} & 6 \mathrm{~T} 1 \mathrm{a} ; \\
\text { Size: } & 1.2(0.3-1.8) \\
& \text { Site: } \mathrm{P}\end{aligned}$ & NA & $\begin{array}{c}\text { 53-112 } \\
\text { Mean: } 74.6\end{array}$ & None & $6.5(2-12)$ & NA & None & $\begin{array}{c}\text { Mean: } \\
30.3(1-86)\end{array}$ \\
\hline 2009 (16) & $\begin{array}{l}2 \text { Patients } \\
\text { NA }\end{array}$ & $\begin{array}{l}1 \mathrm{~T} 1 \mathrm{a} ; 1 \mathrm{~T} 2 \mathrm{~b} \\
\text { Size: } 2,3 \\
\text { Site: } \mathrm{P}(\mathrm{A}, \mathrm{C})\end{array}$ & GS & $\begin{array}{l}180 \\
120\end{array}$ & $\begin{array}{c}250 \\
50\end{array}$ & $\begin{array}{c}11 \\
4\end{array}$ & SMD & $\begin{array}{l}\text { Bleeding (1 case) } \\
\text { from port site } \\
\text { treated with } \\
\text { re-laparoscopy; } \\
1 \text { R1 case (T2b) } \\
\text { treated with LATG }\end{array}$ & $\begin{array}{l}\text { Mean: } \\
8.5(1-24) \\
\text { G }\end{array}$ \\
\hline 2014 (17) & $\begin{array}{l}1 \text { Patient } \\
\text { NA }\end{array}$ & $\begin{array}{c}1 \text { T1a; } \\
\text { Size: }<4-5 \mathrm{~cm} \text {; } \\
\text { Site: } \mathrm{C}\end{array}$ & GS & NA & NA & NA & NA & NA & NA \\
\hline
\end{tabular}


Table I. Continued

\begin{tabular}{|c|c|c|c|c|c|c|c|c|c|}
\hline $\begin{array}{l}\text { Year/ } \\
\text { reference }\end{array}$ & $\begin{array}{l}\text { Number/ } \\
\text { gender of } \\
\text { patients* }\end{array}$ & $\begin{array}{l}\text { EGC type/ } \\
\text { Size }(\mathrm{cm}) / \\
\quad \text { Site }\end{array}$ & $\begin{array}{c}\text { Means } \\
\text { of } \\
\text { extraction }\end{array}$ & $\begin{array}{l}\text { Operative } \\
\text { time } \\
(\mathrm{min})\end{array}$ & $\begin{array}{l}\text { Blood } \\
\text { loss } \\
(\mathrm{ml})\end{array}$ & $\begin{array}{c}\text { LOS } \\
\text { (mean } \\
\text { days) }\end{array}$ & $\begin{array}{l}\text { Approach to } \\
\text { mucosal } \\
\text { defect }\end{array}$ & $\begin{array}{c}\text { Operative } \\
\text { complications }\end{array}$ & $\begin{array}{c}\text { Follow-up } \\
\text { (months) }\end{array}$ \\
\hline 2015 (18) & $\begin{array}{c}2 \text { Patients } \\
\text { NA }\end{array}$ & $\begin{array}{c}\text { EGC type: NA; } \\
\text { Size: NA; } \\
\text { Site: C }\end{array}$ & GS & NA & NA & NA & SMD & NA & NA \\
\hline 2007 (19) & 3 Pigs* & $\begin{array}{c}\text { T1a and } \mathrm{T} 1 \mathrm{~b} \\
\text { Size }<5 \mathrm{~cm} ; \\
\text { Site: } 1 \mathrm{~A}, 2 \mathrm{P}(\mathrm{NWA})\end{array}$ & VLS & NA & NA & NA & SMD & None & Short (NA) \\
\hline 2007 (20) & $\begin{array}{l}1 \text { Porcine } \\
\text { model* }\end{array}$ & $\begin{array}{l}2 \text { Tentative EGCs; } \\
\text { Size: } 5.5 \times 3 ; 7 \times 3.6 \text {; } \\
\text { Site: } P(C)\end{array}$ & $\begin{array}{c}\text { Trocar } \\
\text { (robotics) }\end{array}$ & Mean: 12 & N.A. & NA & SMD & N.A. & N.A. \\
\hline
\end{tabular}

LOS: Length of stay; NA: not assessed; P: posterior wall; B: gastric body; C: cardia; A: antrum; VLS: videolaparoscopy via trocar; UMD: untreated mucosal defect; GS: gastroscopy via mouth; SMD: sutured mucosal defect; fu: follow-up; PEG: percutaneous endoscopic gastrostomy; EGCS: early gastric cancer stump; DG: distal gastrectomy; LATG: laparoscopic-assisted total gastrectomy. *Pigs or porcine models.

surgical oncological highlights and weak points of this interesting procedure.

\section{Conflicts of Interest}

The Authors declare no conflicts of interest in regard to this study.

\section{References}

1 Ntourakis D and Mavrogenis G: Cooperative laparoscopic endoscopic and hybrid laparoscopic surgery for upper gastrointestinal tumors: current status. World J Gastroenterol 21: 12482-12497, 2015.

2 Ohashi S: Laparoscopic intra-gastric surgery for early gastric cancer: a new technique in laparoscopic surgery. Surg Technol Int 3: 221-226, 1994.

3 Ohashi S: Laparoscopic intraluminal (intragastric) surgery for early gastric cancer. Surg Endosc 9: 169-171, 1995.

4 Lai DT, Chu KM and Storey DW: Laparoscopic endoluminal gastric surgery. Aust N Z J Surg 66: 41-21, 1996.

5 Ohgami M, Otani Y, Kumai K, Kubota T, Kim YI and Kitajima M: Curative laparoscopic surgery for early gastric cancer: five years experience. World J Surg 23: 187-193, 1999.

6 Ohgami M, Otani Y, Furukawa T, Kubota T, Kumai K and Kitajima M: Curative laparoscopic surgery for early gastric cancer: eight years experience. Nihon Geka Gakkai Zasshi 101: 539-545, 2000.

7 Hüscher CG, Anastasi A, Crafa F, Recher A and Lirici MM: Laparoscopic gastric resections. Semin Laparosc Surg 7: 26-54, 2000.

8 Taniguchi $\mathrm{E}$, Ohashi $\mathrm{S}$, Takiguchi $\mathrm{S}$, Yumiba $\mathrm{T}$, Itoh $\mathrm{T}$, Matsuda $\mathrm{H}$ and Nakajima K: Laparoscopic intragastric surgery using a radially expandable sleeve. Surg Endosc 14: 505-507, 2000

9 Ludwig K, Wilhelm L, Scharlau U, Amtsberg G and Bernhardt $\mathrm{J}$ : Laparoscopic-endoscopic rendezvou resection of gastric tumors. Surg Endosc 16: 1561-1565, 2002.
10 Yumiba T, Ito T, Kushima H, Taniguchi E, Inoue Y, Nishida T, Kitagawa T, Nishikawa K, Ohashi S and Matsuda H: Effect of mucosal suture on the healing of mucosal defect in laparoscopic intragastric surgery. Gastric Cancer 6: 96-99, 2000.

11 Bernhardt J, Ludwig K, Ptok H, Wilhelm L, Stier A and Heidecke CD: Minimally invasive options for gastric tumors. Zentralbi Chir 128: 566-572, 2003.

12 Shimizu S, Noshiro H, Nagai E, Uchiyama A and Tanaka M: Laparoscopic gastric surgery in a Japanese institution: analysis of the initial 100 procedures. J Am Coll Surg 197: 372-378, 2003.

13 Takiguchi S, Sekimoto M, Fujiwara Y, Yasuda T, Yano M and Monden M: Laparoscopic intragastric surgery for gastric tube cancer following esophagectomy. Surg Endosc 17: 1322-1325, 2003.

14 Kobayashi T, Kazui T and Kimura T: Surgical local resection for early gastric cancer. Surg Laparosc Endosc Percutan Tech 13: 299-303, 2003.

15 Ludwig K, Klautke G, Bernhard J and Weiner R: Minimally invasive and local treatment for mucosal early gastric cancer. Surg Endosc 19: 1362-1366, 2005.

16 Wong DC, Wong SK, Leung AL, Chung CC and Li MK: Combined endolaparoscopic intragastric excision for gastric neoplasms. J Laparoendosc Adv Surg Tech A 19: 765-770, 2009.

17 Conrad C, Nedelcu M, Ogiso S, Aloia TA, Vauthey JN and Gayet B: Laparoscopic intragastric surgery for early gastric cancer and gastrointestinal stromal tumors. Nn Surg Oncol 21: 2620, 2014.

18 Marshall MB and Haddad NG: Laparoscopic intragastric approach for gastroesophageal leiomyoma and cancer. J Thorac Cardiovasc Surg 149: 1210-1212, 2015.

19 Hoya Y, Yamashita M, Sasaki T and Yanaga K: Laparoscopic intragastric full-thickness excision (LIFE) of early gastric cancer under flexible endoscopic control-introduction of ne technique using animal. Surg Laparosc Endosc Percutan Tech 17: 111-115, 2007.

20 Hirano Y, Ishikawa N, Omura K, Inaki N, Hiranuma C, Waseda R and Watanabe G: Robotic intragastric surgery: a new surgical approach for the gastric lesion. Surg Endosc 21: 2112-2114, 2007. 
21 Goto O, Takeuchi H, Kawakubo H, Sasaki M, Matsuda T, Matsuda S, Kigasawa Y, Kadota Y, Fujimoto A, Ochiai Y, Horii J, Uraoka T, Kitagawa $\mathrm{Y}$ and Yahagi N: First case of nonexposed endoscopic wall-inversion surgery with sentinel node basin dissection for early gastric cancer. Gastric Cancer 18: 434439, 2015.

22 Hur H, Lim SG, Byun C, Kang JK, Shin SJ, Lee KM, Kim JH, Cho YK and Han SU: Laparoscopy-assisted endoscopic fullthickness resection with basin lymphadenectomy based on sentinel lymph nodes for early gastric cancer. J Am Coll Surg 219: 29-37, 2014.

23 Abe N, Mori T, Takeuchi H, Ueki H, Yanagida O, Masaki T, Sugiyama M and Atomi Y: Successful treatment of early stage gastric cancer by laparoscopy-assisted endoscopic full-thickness resection with lymphadenectomy. Gastrointest Endosc 68: 12201224, 2008.

24 Cho WY, Kim YJ, Cho JY, Bok GH, Jin SY, Lee TH, Kim HG, Kim JO and Lee JS: Hybrid natural orifice transluminal endoscopic surgery: endoscopic full-thickness resection of early gastric cancer and laparoscopic regional lymph node dissection14 human cases.Endoscopy 43: 134-139, 2011.

25 Nunobe S, Hiki N, Gotoda T, Murao T, Haruma K, Matsumoto H, Hirai T, Tanimura S, Sano T and Yamaguchi T: Successful application of laparoscopic and endoscopic cooperative surgery (LECS) for a lateral-spreading mucosal gastric cancer.Gastric Cancer 15: 338-342, 2012.

26 Virgilio E, Giarnieri E, Giovagnoli MR, Montagnini M, Proietti A, D'Urso R, Mercantini P, Balducci G and Cavallini M: Early gastric cancer exfoliating into gastric lavage (GL1 EGC) shows a more aggressive behavior and poorer survival compared tot he non-exfoliative counterpart (GL0 EGC). Anticancer Res 37: 4199-4203, 2017.

27 Virgilio E, Giarnieri E, Giovagnoli MR, Montagnini M, Proietti A, D'Urso R, Nigri G, Mercantini P, Ramacciato G, Cavallini M and Balducci G: Presence of cancer cells in gastric lavage of gastric cancer patients as an indicator of advanced disease, predictor of tumour aggressive phenotype and independent prognostic factor for poor survival: The endoluminal metastatic pathway of gastric cancer and GL0/GL1 classification. Cytopathology 29: 41-48, 2018.
28 Virgilio E, Giarnieri E, Montagnini M, D’Urso R, Proietti A, Mesiti A, Giovagnoli MR, Mercantini P, Cavallini M and Balducci G: Detection of cancer cells and tumor markers in gastric lavage of patients with gastric cancer: Do these findings have a clinicopathological significance and oncological implication? Med Hypotheses 94: 1-3, 2016.

29 Virgilio E, Giarnieri E, Montagnini M, D’Urso R, Proietti A, Mesiti A, Giovagnoli MR, Mercantini P, Cavallini M and Balducci G: Analyzing gastric lavage of gastric cancer patients: a prospective observational study on cytopathology and determination of intragastric CEA, Ca 19.9, Ca 72.4 and Ca 50. Acta Cytol 60: 161-166, 2016.

30 Virgilio E, Balducci G, Mercantini P, Giarnieri E, Giovagnoli MR, Montagnini M, Proietti A, D’Urso R and Cavallini M: Utility of nasogastric tube for medical and surgical oncology of gastric cancer: a prospective institutional study on a new and precious application of an old and economic device. Anticancer Res 38: 433-439, 2018.

31 Virgilio E, Proietti A, D’Urso R, Cardelli P, Giarnieri E, Montagnini M, Giovagnoli MR, Mercantini P, Balducci G and Cavallini M: Measuring intragastric tumor markers in gastric cancer patients: a systematic literature review on significance and reliability. Anticancer Res 37: 2817-2821, 2017.

32 Virgilio E, Scorsi A, Amodio PM, Goglia A and Macarone Palmieri R: Port site recurrences following laparoscopic liver resection for hepatocellular carcinoma. World J Surg 40: 17789, 2016.

33 Virgilio E, Scorsi A, Abu Samra S, Goglia A and Macarone Palmieri R: Trocar-site recurrences following laparoscopic and robotic resection of gynecologic malignancies. J Minim Invasive Gynecol 24: 683, 2017.

$34 \mathrm{Yu}$ XF, Ma YY, Hu XQ, Zhang QF and Ye ZY: Analysis of exfoliated gastric carcinoma cells attached on surgical supplies. Onco Targets Ther 7: 1869-1873, 2014.

Received January 12, 2018

Revised February 9, 2018

Accepted February 13, 2018 